\title{
Concentration Profiles Among Shooting Student Athletes
}

\author{
Miftakhul Jannah, Lina Halimatussa'diyah, Rachman Widohardhono \\ Department of Psychology \\ Universitas Negeri Surabaya \\ Surabaya, Indonesia \\ miftakhuljannah@unesa.ac.id
}

\begin{abstract}
Basically every sport must have high concentration ability. The concentration ability possessed by athletes has an important role for each athlete to maintain performance during a match. The purpose of this study was to determine the profile of concentration on student athletes in shooting sports. Where mental aspects are very important to increase concentration on student athletes. The method in this study used descriptive statistics by using a concentration test instrument namely the Grid Concentration exercise wherein the test kit contained numbers from 00 to 99 where athletes had to sequence numbers from the smallest to the numbers that the biggest. The subjects in this study were student athletes in shooting sports, which amounted to 84 samples consisting of 50 male athletes and 34 female athletes. The results of this study are interesting where the diversity of concentration skills in student athletes shooting villages is influenced by several other mental aspects so that because of the varying levels of concentration of athletes, the trainer must provide appropriate training in increasing the concentration of athlets. shows that in students shooting athletes, athlete concentration.
\end{abstract}

\section{Keywords - concentration; athlete; shooting}

\section{INTRODUCTION}

Athletes are one of the professions that are in great demand by Indonesians today. Because being an athlete in addition to the profession as well as the distribution of hobbies that are liked. Moreover, there are many sports at this time that have started to enter Indonesia. Sport is one of the important elements in human life. Exercise is a series of organized and planned gestures performed by someone consciously to improve their functional abilities [1]. Exercising regularly can provide benefits for the health of the human body, exercise is also an activity that can train the human body not only physically but also mentally [2].

One of the sports that is currently developing in Indonesia, namely shooting sports. The development of shooting sports can be seen from the number of new athletes in shooting sports and from the many participants who took part in the matches held by shooting clubs, regional administrators and also the large management of the Indonesian Association of Hunting and Shooting Sports. Shooting sports is one sport that is expected to be able to foster young Indonesians into strong, energetic, hardworking and never give up challenges in the future. Thus shooting sports will give birth to many qualified athletes and can bring Indonesian names to the National and International scene [3].

In competing athletes are required to be able to have high concentration in order to be able to win the game. Nideffer and Sagal explain that concentration is a constant change related to two dimensions, namely dimensions of width or width (broad or narrow) and dimensions of concentration or focus (internal or external) [2]. Athletes who have good physical endurance, strength of the muscles of the arms and hands, and good technical knowledge and tactics will not be able to give high points if the shot is shot is not on target [4]. Starting from preparing shots, directing shots to targets, athletes must be able to ensure their concentration and focus to be maintained. So, it can be said that in every shooting activity the athlete must have a qualified concentration. If the athlete's concentration is divided, especially in the event that the athlete will open fire, then most likely the shot will not be able to hit the desired target [5].

The same thing happened to student athletes where when the match starts, it appears that athletes who have not been able to keep their focus on the target of the shot, so that shots are often shot missed or not in accordance with the target to be achieved. In addition, it often happens during training that athletes have trained and learned many techniques to be able to reach the target, but at the field of competition athletes are not able to release the techniques they have learned. When going to shoot the athlete's shot looks less in his breathing arrangement so the aim is not on target [5].

Concentration is the athlete's ability to focus attention and mind only on information that is important for the success of its performance in a match [6]. When athletes are in a state of concentration, athletes will sort information or stimuli that do not facilitate their performance and focus only on information that is important for their victory. without good concentration, athletes can make various errors in performance in the competition, for example the failure to display techniques that have been learned, lack of accurate sports movements that should be done, or in Archery can also mean the failure of athletes to shoot targets with high points [7].

In student athletes, where athletes are still lacking in training due to time and schedule constraints with learning, so that student athletes do not intensely maintain training time more 
intensely [5]. Based on the results of interviews conducted by athletes often lose their concentration when firing a target, losing concentration to the athlete is seen when the athlete is unable to focus on one point, namely shot, the athlete still pays attention and thinks of things outside his game, for example athletes who continue thinking about the surroundings is compared with a focus on performance on the field, it happens because athletes often see opponent's shots which he thinks the shot looks good so the athlete does not concentrate with his own shot [8]. Athletes also say that they have lost their matches or suffered defeats caused by loss of concentration because athletes feel inferior to the results obtained by their opponents, they are afraid because the weather conditions are uncertain, the conditions of the match are not the same as those at training, and the audience's screaming so that the athlete's focus and attention is no longer on the game but on other things.

Nideffer and Sagal [2] suggest the dimensions of concentration, one of which is focus, in this case influenced by two things, namely the extent of attention and direction of attention. One's attention can expand or narrow with the direction it can go outside or inside. Therefore, a person's concentration can be affected by disturbances originating from inside and outside him. Some disorders that come from yourself include thinking about events (failures) that have just passed, thinking about the results to be achieved, feeling suffocated and depressed, physiological disorders, fatigue, and lack of motivation. Whereas external disturbances include striking stimuli, loud sounds, and the role of nerve lines performed by the opponent.

The purpose of this study was to determine the level of concentration in student athletes wherein in shooting athletes have low and high criteria depending on the status of the athlete namely senior and junior. From that, it can be seen how much the level of concentration is on the student athlete.

\section{METHOD}

This study uses descriptive quantitative research methods. In this study the data collection instrument in this study used the Grid Concentration Exercise adopted from Harris and Harris [4]. This tool is used to measure the athlete's concentration, in the form of a table containing numbers 0 to 99 . The subject is asked to connect with the numbers of the numbers from the smallest number to the next larger number in one minute. Assessment is done by calculating the highest number achieved minus errors made. The higher the score obtained, the higher the concentration level of a person. The subjects in this study were 84 student athletes shooting where 50 were male athletes and 34 were female athletes.

\section{RESUlTS AND DISCUSSION}

This study involved 84 athletes of shooting as a research sample. The description of the research data shows that the average of the concentration variables is 9.3 with a minimum value of concentration is 3 while the maximum is 17 . The standard deviation value is 3.16. From the results of the statistical test, the categorization of standard deviations is obtained by athletes who have a score up to 12,46 , the concentration of athletes in high categorization, while athletes who have a score of in $6.16<\mathrm{x}<12.46$, the concentration of athletes is in moderate categorization and if athletes have a score of under 6.16, the concentration of athletes falls into low categorization.

Concentration is a situation when athletes are able to focus their attention and thoughts on only one information at a time[1]. When an athlete in a state of concentration the athlete will sort and ignore the other stimuli that are around him and only focus on his movements. concentration involves the ability to pay attention to what is happening, the extent to which individuals can attend, and how long individuals can continue to pay attention to what is happening around them [10]. Concentration involves attention which is where individuals are able to choose to pay attention to certain things that occur or ignore others, as well as the ability to place the mind on one thing at a time or on all things related to what happened at that time [11]. Basically, an athlete must be able to focus the mind and ignore the stimuli that are felt disturbing [3].

In accordance with Wilson, Paper and Schmidt [7] who state that concentration is a form of concentration at one point and is not affected by the presence of stimuli from internal and external athletes. Basically when athletes are capable of regulating emotions or controlling the emotions of athletes in the field so that athletes can change emotional expressions, reduce the negative impact of athlete's emotions both in physical and psychological effects, of course, will play an important role in increasing concentration in shooting [2].

The results of the analysis showed that the concentration of athletes in high categorization got a score of 20,23 percent while in the moderate categorization was 61,90 percent and in the low categorization received 17,83 percent. These results show the diversity of concentration skills in student athletes shooting villages. These results indicate that for beginner student athlete the scores obtained are included in low categorization, while for student athletes who are seniors, they tend to get higher scores [12]. In the psychology of sports the concentration of athlete is influenced by many things, namely the many other important mental aspects that influence the concentration level of student athletes. Anxiety is an internal distractor that affects the concentration of athletes [6]. Athletes that have high anxiety, means that stimuli that attract attention to athletes become numerous, as an effect athletes fail to selective attention by sorting out the stimuli received by their senses so that their concentration is broken. Another mental aspect that also influences the level of concentration is self-confidence, regulation of emotions etc. So, from that it is important for trainers to provide interventions, for example providing appropriate training to increase the concentration of athlete. Quiet eye training can increase concentration on badminton athletes, self-hypnosis training can increase concentration in rhythmic gymnastics athletes positive self-talk training is able to increase concentration in archery athletes. So it is important for the trainer to provide concentration training outside of dexterity training and to improve the athlete's performance [3]. 


\section{CONCLUSION}

Based on the results of the research conducted, it can be concluded that concentration in shooting sports is needed. When athletes are able to maintain their concentration during a match, the athlete's performance will remain stable. However, due to lack of training carried out by student athletes, the concentration level is low.

\section{REFERENCES}

[1] D. A. Garvin, "The processes of organization and management," Sloan Manage. Rev., vol. 39, no. 4, pp. 33-51, 1998.

[2] N. Ongko and M. Jannah, "Pengaruh Mind Control Training Terhadap Peningkatan Konsentrasi Pada Atlet Putri UKM Bola Voli Unesa," $J$. Psikol. Teor. dan Terap., vol. 7, no. 1, pp. 16-25, 2016.

[3] M. Rafliliya Triananda P, "Pengaruh self-talk positif terhadap konsentrasi pada atlet panahan," Character J. Penelit. Psikologi., vol. 4, no. 2, 2017.

[4] D. V Harris and B. L. Harris, The athlete's guide to sports psychology:
Mental skills for physical people, vol. 1. Human Kinetics, 1984.

[5] R. J. Butler and L. Hardy, "The performance profile: Theory and application," Sport Psychol., vol. 6, no. 3, pp. 253-264, 1992.

[6] R. M. Nideffer, The ethics and practice of applied sport psychology. Mouvement publications, 1981.

[7] I. M. A. Fitri Sholichah, "Pengaruh pelatihan quiet eye training terhadap peningkatan konsentrasi pada atlet bulutangkis," Character J. Penelit. Psikologi., vol. 3, no. 3, 2015.

[8] P. J. Cohn, "An exploratory study on peak performance in golf," Sport Psychol., vol. 5, no. 1, pp. 1-14, 1991.

[9] K. A. Ericsson and J. Starkes, "Development of elite performance and deliberate practice," Expert Perform. Sport. Adv. Res. Sport Expert., pp. 49-83, 2003.

[10] C. Approaches and I. Curriculum, Access to Academics for ALL Students. .

[11] A. W. Little, "Multigrade teaching: towards an international research and policy agenda," Int. J. Educ. Dev., vol. 21, no. 6, pp. 481-497, 2001.

[12] M. W. Eysenck and M. T. Keane, Cognitive psychology: A student's handbook. Psychology press, 2015. 